\title{
Možnosti rehabilitace u pacientů po prodělaném onemocnění covid-19
}

Koncem roku 2019 se v Číně objevil nový typ koronaviru (SARS-CoV-2), který způsobil světovou pandemii nemoci covidu-19. Toto onemocnění může mít asymptomatickou nebo lehkou formu, ale takéstředně těžký, těžký či dokonce velmi těžký průběh, který může vést až k smrti pacienta.

U většiny pacientů, kteřínemoc covid-19prodèlali, se neobjevujížádné následky této nemoci. Nicméněje řada pacientů, kteří po odeznění akutní fáze nemoci pocitují obtiže, kteréjenegativněovlivňujípřivykonáváníběžných denních činností, pohybových aktivit, v pracovní činnosti iúčasti na společenském životě. Stěžují si, že jejich tělo "nefunguje" po prodělané nemoci covid-19 tak, jak byli dríve zvyklí. Mezinejčastějšípríznaky patřídechovéobtiže, únava, bolest svalů a jejich oslabení, dechově podmíněná redukce tolerance zátěže, bolestina hrudi, kašel, potiže se spánkem, zažíváním, změny nálad a deprese.

Pravidelná pohybová aktivita zlepšuje imunitní odpověd' na infekční nemoci včetně infekce SARSCoV-2 (1) a může se tak podílet na snížení závažnosti nemoci covid-19 a na snižení jejích následků. Předpis pohybové aktivity a rehabilitační léčba je taknedílnou součástí postcovidové péče (2).

Rehabilitační léčba zahrnuje vstupní a výstupní vyšetření, edukaci, pohybovou léčbu, techniky respirační fyzioterapie a další fyzioterapeutické postupy. Cílem respirační fyzioterapie je reedukace optimál- ního dechového vzoru, zvýšení rozvíjení hrudníku, zvýšení sily dýchacích svalů a usnadnění odkašlávání. Využiváme k tomu aktivní dechové techniky. Ty lze také provádět s dechovými trenažéry pro posílení nádechových a výdechových svalů či pro usnadnění odkašlávání. Pohybová léčba zahrnuje vytrvalostní a silový trénink na zvýšení kardiopulmonální zdatnosti a posílení svalů trupu a končetin. Podrobné informace k jednotlivým technikám plicní rehabilitace je možné najít v Doporučeném postupu plicní rehabilitace u onemocnèní covid-19 (3).

Je celá řada pacientů, jejichž přiznaky jsou po prodělaném onemocnění covid-19 mírné a hledají radu lékaře či fyzioterapeuta, jak se postupně navrátit k pohybovým aktivitám a cvičením, které vykonávali před onemocněním. Jak aktivně prispět ke zlepšení svého zdravotního stavu v domácím prostředí? Základní pravidla pro cvičení a pro návrat k pohybovým aktivitám a jednotlivé ukázky možných cviků jsou uvedeny v brožurce "Možnosti rehabilitace u pacientů po prodělaném onemocnění covid-19". Ta je volně ke stažení na webových stránkách Fakultní nemocnice Olomouc (4). Nalezneme zde i přehlednou tabulku, kdy začít s pohybovou aktivitou dle tíže průběhu nemoci. Kombinace jednotlivých cviků, počet opakování, délka a intenzita cvičení bude vždy záležet na aktuálním zdravotním stavu a přidružených onemocněních.
Naším přáním je, aby se pacienti po prodělaném onemocnění covid-19 mohli co nejrychleji plně zapojit do svého běžného života, byli bez obtíží a plni sil.

I psychiatři by o této možnosti měli vědět, protože i oni mohou brožurku doporučovat svým pacientům, pro které je pohybová aktivita prospěšná.

Mgr. Monika Mikulášková',2,

Mgr. Barbora Imrichovál, 2 doc. Mgr. Kateřina Neumannová, Ph.D. ${ }^{3}$ ${ }^{\top}$ Klinika tělovýchovného lékařství a kardiovaskulární rehabilitace, FN Olomouc ${ }^{2}$ LF UP, Olomouc ${ }^{3}$ Katedra fyzioterapie, Fakulta tělesné kultury, UP

Olomouc

1. da Silveira MP, da Silva Fagundes KK, Bizuti MR, et al. Physical exercise as a tool to help the immune system against COVID-19: an integrative review of the current literature. Clin Exp Med 2021; 21(1): 15-28.

2. Spruit MA, Holland AE, Singh SJ, et al. Covid-19: Interim Guidance on Rehabilitation in the Hospital and Post-Hospital Phase from a European Respiratory Society and American Thoracic Society-coordinated International Task Force Eur Respir J 2020; 56(6): 2002197. doi: 10.1183/13993003.02197-2020. Online ahead of print. 3. Neumannová K, Zatloukal J, Kopecký M, Vařeka I, Kobližek V. Doporučený postup plicní rehabilitace u onemocnění covid-19. Dostupnéz: http://www.pneumologie.cz/novinka/1813/doporuceny-postup-plicni-rehabilitace-u-onemocneni-covid-19/. 4. Možnosti rehabilitace u pacientů po prodělaném onemocnění covid-19. Edukační materiál pro pacienty. Dostupnéz: https:// telovychova.fnol.cz/uploads/composer/rwggdty458-FNOL Mo\%C5\%BEnosti\%20rehabilitace\%20u\%20pacient\%C5\%AF\%20 po\%20prod\%C4\%9Blan\%C3\%A9m\%20COVID-19.pdf 